\title{
Library Closures and ANZTLA's responsibility of care
}

\author{
Philip Harvey
}

To use the word 'closure' is to conclude that a library is coming to an end of its active life and that decisions have to be made to close it. Such situations have been identified over recent years by members of the Australian and New Zealand Theological Library Association and hopes expressed about possible responses by the Association. The kinds of situations loosely defined as 'library closures' that may' require some response include the following:

1. Libraries closed from public use and which no longer serve any kind of constituency. These would include libraries that have been down graded to the extent that professional information services are no longer provided.

2. Libraries about which it is known decisions to close are being made, but without the input of anyone from the professional library community or the theological community.

3. Libraries known to have no future.

4. Libraries where it is known the collection is to be dispersed, divided or in some other way broken up in whole of in part.

At ANZTLA's Annual General Meeting in July 1999 a proposal was made by Philip Harvey to address this serious ongoing situation.

"ANZTLA, which understands itself to be a body vitally interested in theological collections in this part of the world, has a duty of care for any collections under threat of closure and dispersal. Plainly, collections of theology, religion and associated literature areANZTLA's object of concern.

"Although it has no powers of final say, ANZTLA holds the respect of religious and theological institutions. Its contacts are spread throughout the religious and educational communities. It has a history of informed and responsible action in the areas of collection management, administration and all other fields of library science and service.

"In the Constitution, ANZTLA's stated aims include:

- To provide a forum for interaction between libraries of and others interested in theological and religions libraries.

- To foster the development and improvement of theological and religious libraries.

- To foster interlibrary co-operation on both national and regional levels.

- To foster contacts with other library associations and groups.

"As such ANZTLA could act, within certain limits, to address the question of closures."

At the AGM the Association voted to appoint a Standing Committee. The Committee consists of one representative from each chapter, plus á convenor: 
Denise Hallion (Western Australia)

Philip Harvey (Victoria)

Susan Lockeridge (Queensland)

Tony McCumstie (Victoria)

Beth Prior (South Australia)

Kim Robinson (New South Wales)

Lesley Utting (New Zealand)

A set of procedures was subsequently was subsequently created to guide committee members, as follows:

The Committee's responsibilities are:

1. To listen out for probable, possible or definite library closures.

2. To notify all members of the Committee of all decisions and actions.

Each Committee member/represents their chapter and has the following responsibilities:

1. To work as a central collector of information within the local chapter.

2. To monitor all situations currently under question.

3. To approach the person, committee or institution having final administrative responsibility for the library with statements of awareness of closure.

4. To offer a consultation, ie to visit the library, to advise and to negotiate.

In light of the consultation,

5. To draft a statement of advice for the consideration of those responsible for the library, to be submitted to them by a given date.

Consultation time should be no more than three hours.

The consultation document contains relevant proposals for the library in question. This may include advice on proper disposal of library materials in consultation with the Committee member or other ANZTLA rnembers and those responsible for the collection.

Major considerations for the Standing Committee are:

1. Creating a network that can communicate quickly.

2 Having action plans in place that can be initiated with ease.

3. Being able to monitor development regularly.

4. Preparing groundwork for potential developments.

5. Assessing the central and often decisive issue of ownership of a given collection.

6. Taking into account the actual capacity of potential receiving libraries adequately to process, house and maintain materials given into their care.

7. Judging whether a library is seeking actvie intervention or is simply asking for support.

The Standing Committee is required to meet at each annual conference and to table a report of the year's negotiations at the AGM. 